\title{
Semen quality and sperm ultrastructure of Himalayan snowtrout Schizothorax plagiostomus Heckel, 1838
}

\author{
GAURAV BHATT, SHURVEER SINGH, VIVEK BAHUGUNA, ASHISH K. CHOWDHARY, \\ SIDDHANT BHARDWAJ AND S. N. BAHUGUNA* \\ Department of Zoology and Biotechnology, Hemwati Nandan Bahuguna Garhwal University, Srinagar Garhwal - 246174 \\ Uttarakhand, India \\ e-mail:profsnbahuguna@rediffmail.com
}

\begin{abstract}
The aim of this study was to characterise physical and biochemical aspects of semen as well as to investigate the fine structure of spermatozoa of the Himalayan snowtrout Schizothorax plagiostomus Heckel, 1838 using scanning and transmission electron microscopy. The species breed twice in a year and semen was collected during both seasons, i.e. from 24 males in February and March, 2015 and from 30 males in September and October, 2015. Size of the fish ranged from 13.5 to 36 $\mathrm{cm}$ in February-March and 12.3 to $38 \mathrm{~cm}$ in September-October. The mean milt volume (ml), sperm density $\left(\times 10^{10} \mathrm{ml}^{-1}\right)$ and spermatocrit (\%) values were $2.25 \pm 1.26,2.22 \pm 0.53$ and $78.87 \pm 8.25$ in February-March and $2.12 \pm 1.25,2.12 \pm 0.52$ and 75.54 \pm 8.23 in September-October respectively. Biochemical parameters of seminal plasma viz., total protein $\left(\mathrm{g} \mathrm{dl}^{-1}\right)$, carbohydrates $\left(\mathrm{mg} \mathrm{dl}^{-1}\right)$ and total lipids were $0.312 \pm 0.05,1.348 \pm 0.07$ and $26.4 \pm 2.23$ in February-March and 0.340 \pm 0.05 , $1.34 \pm 0.1$ and $26.4 \pm 3.19$ in September-October respectively. Scanning and transmission electron microscopy studies of sperm revealed that the sperm was composed of an ovoid shaped head without acrosome, ellipsoidal midpiece with mitochondria and tail or flagellum. Flagellum had a typical 9+2 axoneme arrangement. The mean length $(\mu \mathrm{m})$ of head, midpiece, flagella and total length of sperm were $1.82 \pm 0.24,0.35 \pm 0.07,20.18 \pm 0.79$ and $22.3 \pm 3$ respectively. For both the breeding seasons, sperm motility decreased significantly with time post-activation.
\end{abstract}

Keywords: Semen, Snow trout, Sperm density, Ultrastructure

\section{Introduction}

Fish semen or milt is composed of spermatozoa and seminal plasma. Both these components are necessary for the viable fertilisation of eggs. The success of fertilisation mainly depends on the qualitative and quantitative characteristics of semen produced by males (Alavi et al., 2008). These characteristics could provide necessary information to determine optimum time for sperm collection, as well as for optimising short-term and long-term storage protocols for artificial fertilisation (Linhart et al., 2004).

The quality of sperm, which is the measure of ability of sperm to successfully fertilise egg is highly variable and depends on various external factors such as feeding regime, quality of feed and environmental temperature (Adewumi et al., 2005; Islam and Akhter, 2011). There are several parameters which are used in sperm quality assessment viz., sperm morphology, semen production indices (sperm volume and density), sperm motility and seminal plasma composition (Stoss, 1983; Billard et al., 1995; Linhart et al., 2000; Rurangwa et al., 2004; Alavi and Cosson, 2006). Sperm velocity has also been used for the evaluation of sperm quality (Lahnsteiner et al., 1996).
Morphological and ultrastructural studies of fish sperm have unveiled great diversity which have been utilised in building phylogenetic relationships among species (Jamieson, 1991). Diversity of sperm ultrastructure is attributed to the adaptation to different mechanisms of fertilisation (external and internal) as well as related environmental parameters of the fertilisation medium.

Sperm fine structure should not only be considered from a systematic, taxonomic point of view but also under the aspect of functionality. An optimal shape of the sperm head is important for its penetration through the micropyle as well as for optimal hydrodynamic properties during motility (Baccetti, 1984; Wei et al., 2007; Furbock et al., 2009). Seminal plasma is a critical component of semen that has an imperative role in sperm motility, function, survival and sperm metabolism. Spermatozoa are protected from oxidative damage by several antioxidants and antioxidant enzymes, which are present in the seminal plasma and spermatozoa (Billard et al., 1995; ShaliutinaKolesova et al., 2013). Investigations of seminal plasma parameters are crucial for the comprehension of essential metabolic processes occurring amid the maturation of sperm in the testis of male, for the unconstrained motility 
of sperm in the sperm conduit and for triggering of sperm motility just after release into the outside environment (Cosson et al., 1999; Morisawa et al., 1999; Miura and Miura, 2003; Cosson, 2004; Alavi et al., 2007).

Schizothorax plagiostomus Heckel, 1838 commonly called snow trout is geographically distributed in various rivers, lakes and tributaries all throughout Himalayas reaching out to limits of China, eastern Afghanistan, Pakistan, Turkistan, Nepal, Tibet, Bhutan and North-east India (Day, 1958). S. plagiostomus is an important food fish of Himalayan population in India including Kashmir, Himachal Pradesh, Uttarakhand, Uttar Pradesh foot hills and Assam. The present study attempted to characterise semen quality as well as to explore the ultrastructure of sperm by means of scanning and transmission electron microscopy in the snow trout $S$. plagiostomus.

\section{Materials and methods}

\section{Fish collection}

Male S. plagiostomus ( $\mathrm{n}=54)$ (weight range : 80 - $750 \mathrm{~g}$ ) were collected from Alaknanda River at Srinagar Garhwal, Uttarakhand $\left(30^{\circ} 13^{\prime} 22.3^{\prime \prime} \mathrm{N} ; 7^{\circ} 48^{\prime}\right.$ 22.8" E) during the month of February-March, 2015 $(n=24)$ and September-October, $2015(n=30)$. Ripe male brooders were easily distinguishable due to presence of several tubercles on the snout.

Semen samples were collected in $2 \mathrm{ml}$ graduated cryovials by gently pressing the abdomen of brooders and kept at $0-4^{\circ} \mathrm{C}$ with ice packs. Proper care was taken to keep off urine, faeces or blood contamination. Semen volume was determined directly by taking the reading from graduated cryovials. Males were weighed and measured before semen collection.

\section{Spermatocrit, sperm density and motility parameters}

Spermatocrit was estimated as per the method described by Vinod and Basavaraja (2010). Sperm density was determined using a Neubauer improved counting chamber (Marienfeld, Tiefe depth profoundeur $0.100 \mathrm{~mm}$ ) after diluting 8000 times with $\mathrm{NaCl}$ solution $(0.7 \%)$ (Agarwal and Raghuvanshi, 2009). Sperm density was calculated using the formula:

Sperm density $\left(\mathrm{ml}^{-1}\right)=(\mathrm{X} \times 8000) / 0.0001$

where, $\mathrm{X}=$ average number of sperm in large squares of Neubauer improved chamber; $8000=$ dilution factor; $0.0001=$ volume of large square in $\mathrm{ml}$.

Motility percentage was estimated as per Aliniya et al. (2013) at different time inervals post-stripping $(1,24$ and $48 \mathrm{~h})$ and post-activation $(15,30$ and $45 \mathrm{sec})$ at $4^{\circ} \mathrm{C}$ as well as at room temperature. $\mathrm{NaCl}$ solution $(0.3 \%)$ was used for activation of sperm. Motility was recorded using a camera (Nikon DS-Fi1, Software NIS element F) mounted on a phase contrast inverted microscope (Nikon ECLIPSE TS100). Bovine serum albumin (0.1\%) was used to prevent sticking of sperm to the slides.

\section{Seminal plasma parameters}

To collect seminal plasma, semen samples were centrifuged in a table top centrifuge (TARSONS SPINWIN MC-01) at $10000 \mathrm{~g}$ for $10 \mathrm{~min}$. Supernatant collected was once again centrifuged for $10 \mathrm{~min}$ to avoid any sperm cells in seminal plasma (Cejko et al., 2014).

Total protein content of seminal plasma was estimated following Lowry et al. (1951); total lipid as per Bligh and Dyer (1959) and total carbohydrates following the method described by McCredy et al. (1950).

\section{Sperm morphology}

For ultrastructure studies of the sperm, samples were made free of seminal plasma by centrifugation (1000 $g, 5 \mathrm{~min})$ in $0.1 \mathrm{M}$ phosphate buffer (PB, pH 7.4). The supernatant was discarded and samples were then fixed using $2 \%$ paraformaldehyde with $2.5 \%$ glutaraldehyde in $0.1 \mathrm{M} \mathrm{PB}(\mathrm{pH} \mathrm{7.4)}$ for $2-3 \mathrm{~h}$ at $4^{0} \mathrm{C}$. Samples were then centrifuged in $\mathrm{PB}$ for $5 \mathrm{~min}$ to remove the fixative. For scanning electron microscopy (SEM), pellets were resuspended in buffer, air-dried, sputter-coated with colloidal gold and observed under a Scanning Electron Microscope (JSM6100, Jeol) at Punjab University, Chandigarh. Transmission electron microscopy (TEM) was carried out as per Barsagade and Garade (2014) in Morgagni 268D Transmission Electron Microscope (Fei Co., The Netherlands) at All India Institute of Medical Sciences (AIIMS), New Delhi, India.

\section{Statistical analysis}

Statistical analyses were performed with the IBM SPSS Statistics 20. Correlations between seminal plasma parameters were analysed using Pearson's correlation test.

\section{Results and discussion}

S. plagiostomus is a Himalayan coldwater fish species which breeds twice in a year during February-March and September-October (Singh et al., 1993). About 15-20 clear tubercles were observed on the snouts of male S. plagiostomus indicating onset of breeding season and maturation of gonads. The semen was observed to be creamy white in colour during both the seasons. Yellowish to pinkish colour of semen was noticed at the time of semen collection due to urine, faecal matter and blood contamination. 


\section{Physical characteristics of semen}

The fish oozed 0.3 to $5 \mathrm{ml}$ of semen $(2.25 \mathrm{ml}$ in February-March and $2.12 \mathrm{ml}$ in September-October) in one ejaculation. At the time of collection, brooders collected from the river were found to immediately ooze out semen and so care was taken to avoid measurement error in semen volume due loss of semen. Significant correlation was observed between milt volume and length of fish during both seasons $(r=0.869$ in February-March and 0.788 in September-October, $\mathrm{p}<0.01$ ) as well as between milt volume and weight of fish $(r=0.818$ in February-March; $r=0.799$ in September-October, $\mathrm{p}<0.01$ ), indicating that large sized males produced more milt than small sized males.

Mean sperm density $\left(\times 10^{10} \mathrm{ml}^{-1}\right)$ and spermatocrit $(\%)$ were 2.22 and 78.87 in February-March and 2.12 and 75.54 in September-October respectively (Table 1). Pearson's correlation test and regression analysis between spermatocrit and sperm density showed a significant positive relationship $(\mathrm{r}=0.872$ in February-March; $\mathrm{r}=0.865$ in September-October),(Fig. 1). This indicates the potential use of regression equation between spermatocrit

Table 1. Descriptive statistics for sampled fish length, weight, milt volume, sperm density, spermatocrit and biochemical parameters of seminal plasma in S. plagiostomus

\begin{tabular}{llllll}
\hline \multirow{2}{*}{ Parameters } & \multicolumn{2}{c}{ Feb-Mar } & & \multicolumn{2}{l}{ Sep-Oct } \\
\cline { 2 - 3 } \cline { 6 - 7 } & $\mathrm{N}$ & Mean $\pm \mathrm{SD}$ & & $\mathrm{N}$ & Mean $\pm \mathrm{SD}$ \\
\hline Length $(\mathrm{cm})$ & 24 & $26.21 \pm 6.45$ & & 30 & $27.36 \pm 5.784$ \\
Weight $(\mathrm{gm})$ & 24 & $269.75 \pm 144.73$ & & 30 & $288.16 \pm 141.93$ \\
Milt volume $(\mathrm{ml})$ & 24 & $2.25 \pm 1.26$ & & 30 & $2.12 \pm 1.25$ \\
Sperm density $\left(\times 10^{10} \mathrm{ml}^{-1}\right)$ & 24 & $2.22 \pm 0.53$ & & 30 & $2.122 \pm 0.52$ \\
Spermatocrit $(\%)$ & 15 & $78.87 \pm 8.25$ & & 19 & $75.542 \pm 8.23$ \\
Total protein $\left(\mathrm{g} \mathrm{dl}^{-1}\right)$ & 24 & $0.312 \pm 0.05$ & & 30 & $0.3403 \pm 0.05$ \\
Carbohydrates $\left(\mathrm{mg} \mathrm{dl}^{-1}\right)$ & 24 & $1.348 \pm 0.07$ & & 30 & $1.34 \pm 0.1$ \\
Total lipid $\left(\mathrm{mg} \mathrm{dl}^{-1}\right)$ & 24 & $26.4 \pm 2.73$ & & 30 & $26.42 \pm 3.19$ \\
\hline
\end{tabular}

$\mathrm{N}$ - Number of samples, SD - Standard deviation
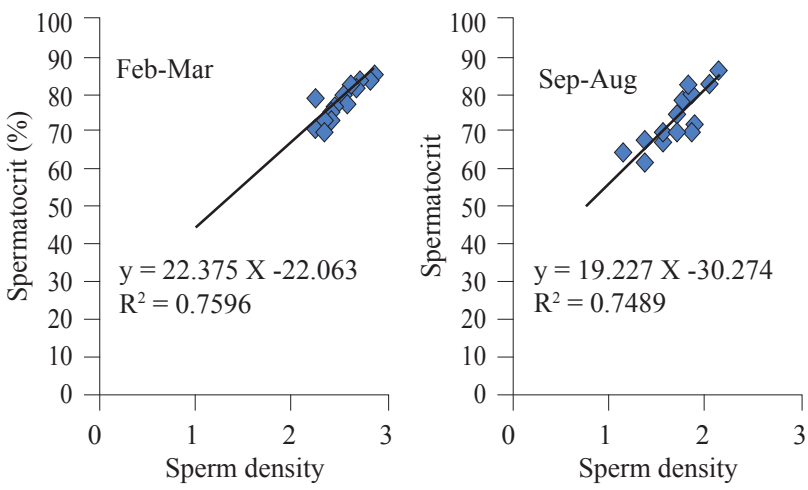

Fig. 1. Regression analysis between spermatocrit and sperm density during the period February-March and September-October for $S$. plagiostomus and sperm density for predicting sperm density in S. plagiostomus as in several other fish groups (Bouck and Jacobson, 1976; Rakitin et al., 1999; Tvedt et al., 2001).

Sperm density has been customarily utilised for the assessment of semen quality owing to its importance in fertilisation success. Estimates of mean sperm density in $S$. plagiostomus is comparatively higher than the previously studied snowtrout species viz., S. richardsonii and Schizothoraichthys progastus (Agarwal and Raghuvanshi, 2009; Agarwal and Raghuvanshi, 2013). The sperm density of S. plagiostomus was also higher than that of Tor khudree (Basavaraja et al., 1998). The sperm production indices of $S$. plagiostomus were observed to be lesser than those of Indian major carps (IMCs), grass carp and silver carp (Verma et al., 2009).

\section{Biochemical characteristics of semen}

Among the basic biochemical parameters, total protein content was highest in the seminal plasma with maximum value observed in September (Table 1). Total protein $\left(\mathrm{g} \mathrm{dl}^{-1}\right)$, carbohydrates $\left(\mathrm{mg} \mathrm{dl}^{-1}\right)$ and total lipids were $0.312,1.348$ and 26.4 in February-March and 0.340, 1.34 and 26.4 in September-October respectively. Total protein content increased with increase in milt volume and sperm density. Total protein showed positive correlation with milt volume $(r=0.555 ; \mathrm{p}<0.01$ in February-March and $r=0.592 ; p<0.01$ in September-October) as well as sperm density $(r=0.473 ; p<0.05$ in February-March and $r=0.655 ; p<0.01$ in September-October) (Table 2).

Carbohydrate and total lipid were present in small amounts compared to proteins and contents were similar in both breeding seasons. These parameters did not show significant correlation with the other parameters. Various elements have been accounted for the regulation of seminal plasma composition such as hormonal mechanisms regulating spermiation during the reproductive season, feeding regime of the broodfish and stripping frequency (Ciereszko et al., 2000; Alavi et al., 2008a; Ciereszko, 2008).

\section{Sperm motility}

Highest sperm motility was observed in February at $15 \mathrm{sec}$ post-activation at $4^{\circ} \mathrm{C}$. For both the breeding seasons, sperm motility decreased significantly as a function of time post-activation. Sperm at $4^{\circ} \mathrm{C}$ showed better quality in terms of motility percentage. After $1 \mathrm{~h}$ of stripping, sperm maintained at $4^{\circ} \mathrm{C}$ and at room temperature showed similar motility percentages. After $24 \mathrm{~h}$, motility percentage of sperm kept at room temperature fell by nearly $30 \%$ at $15 \mathrm{sec}, 60 \%$ at $30 \mathrm{sec}$ and $45 \mathrm{sec}$ post-activation respectively as compared to sperm at $4^{\circ} \mathrm{C}$ (Table 3 ). Motility of the spermatozoa is the 
Table 2. Pearson's correlation and standard error of correlation coefficients between physical and biochemical parameters of milt

\begin{tabular}{|c|c|c|c|c|c|c|c|c|}
\hline \multirow{2}{*}{ Parameters } & \multirow{2}{*}{ Collection period } & \multicolumn{7}{|c|}{ Parameters } \\
\hline & & Length & Weight & Milt volume & Sperm density & Spermatocrit & Total protein & Carbohydrate \\
\hline Weight & $\begin{array}{l}\text { Feb-Mar } \\
\text { Sep-Oct }\end{array}$ & $\begin{array}{l}0.891^{* *} \pm 0.09 \\
0.843^{* *} \pm 0.10\end{array}$ & & & & & & \\
\hline Milt volume & $\begin{array}{l}\text { Feb-Mar } \\
\text { Sep-Oct }\end{array}$ & $\begin{array}{l}0.869^{* *} \pm 0.10 \\
0.788^{* *} \pm 0.11\end{array}$ & $\begin{array}{l}0.818^{* *} \pm 0.12 \\
0.799^{* *} \pm 0.11\end{array}$ & & & & & \\
\hline Sperm density & $\begin{array}{l}\text { Feb-Mar } \\
\text { Sep-Oct }\end{array}$ & $\begin{array}{l}0.902^{* *} \pm 0.09 \\
0.793^{* *} \pm 0.11\end{array}$ & $\begin{array}{l}0.846^{* *} \pm 0.11 \\
0.814^{* *} \pm 0.10\end{array}$ & $\begin{array}{l}0.871^{* *} \pm 0.10 \\
0.722^{* * *} \pm 0.13\end{array}$ & & & & \\
\hline Spermatocrit & $\begin{array}{l}\text { Feb-Mar } \\
\text { Sep-Oct }\end{array}$ & $\begin{array}{l}0.826^{* *} \pm 0.12 \\
0.800^{* *} \pm 0.11\end{array}$ & $\begin{array}{l}0.692^{* *} \pm 0.15 \\
0.711^{* *} \pm 0.11\end{array}$ & $\begin{array}{l}0.544^{*} \pm 0.17 \\
0.627^{* *} \pm 0.14\end{array}$ & $\begin{array}{l}0.955^{* *} \pm 0.06 \\
0.961^{* *} \pm 0.05\end{array}$ & & & \\
\hline Total protein & $\begin{array}{l}\text { Feb-Mar } \\
\text { Sep-Oct }\end{array}$ & $\begin{array}{l}0.417^{*} \pm 0.19 \\
0.759^{* *} \pm 0.12\end{array}$ & $\begin{array}{l}0.331 \pm 0.20 \\
0.669^{* *} \pm 0.14\end{array}$ & $\begin{array}{l}0.555^{* * *} \pm 0.17 \\
0.592^{* *} \pm 0.15\end{array}$ & $\begin{array}{l}0.535^{* *} \pm 0.18 \\
0.629^{* *} \pm 0.14\end{array}$ & $\begin{array}{l}0.434 \pm 0.19 \\
0.511^{*} \pm 0.16\end{array}$ & & \\
\hline Carbohydrate & $\begin{array}{l}\text { Feb-Mar } \\
\text { Sep-Oct }\end{array}$ & $\begin{array}{l}0.402 \pm 0.19 \\
0.384^{*} \pm 0.17\end{array}$ & $\begin{array}{l}0.507^{*} \pm 0.18 \\
0.26 \pm 0.18\end{array}$ & $\begin{array}{l}0.486^{*} \pm 0.18 \\
0.311 \pm 0.17\end{array}$ & $\begin{array}{l}0.406^{*} \pm 0.19 \\
0.378^{*} \pm 0.17\end{array}$ & $\begin{array}{l}0.281 \pm 0.20 \\
0.346 \pm 0.17\end{array}$ & $\begin{array}{l}0.333 \pm 0.20 \\
0.400^{*} \pm 0.17\end{array}$ & \\
\hline Total lipid & $\begin{array}{l}\text { Feb-Mar } \\
\text { Sep-Oct }\end{array}$ & $\begin{array}{l}0.361 \pm 0.19 \\
0.421^{*} \pm 0.17\end{array}$ & $\begin{array}{l}0.386 \pm 0.19 \\
0.35 \pm 0.17\end{array}$ & $\begin{array}{l}0.291 \pm 0.20 \\
0.284 \pm 0.18\end{array}$ & $\begin{array}{l}0.347 \pm 0.19 \\
0.429^{*} \pm 0.17\end{array}$ & $\begin{array}{l}-0.104 \pm 0.21 \\
0.366 \pm 0.17\end{array}$ & $\begin{array}{l}0.106 \pm 0.21 \\
0.354 \pm 0.17\end{array}$ & $\begin{array}{l}0.153 \pm 0.21 \\
0.365^{*} \pm 0.17\end{array}$ \\
\hline
\end{tabular}

**. Correlation significant at $\mathrm{p}=0.01$ (2-tailed).

*. Correlation significant at $\mathrm{p}=0.05$ (2-tailed).

Table 3. Sperm motility percentage

\begin{tabular}{|c|c|c|c|c|c|c|}
\hline \multirow{3}{*}{ Time post-activation (sec) } & \multicolumn{6}{|c|}{ Time post-stripping } \\
\hline & \multicolumn{2}{|c|}{$1 \mathrm{~h}$} & \multicolumn{2}{|c|}{$24 \mathrm{~h}$} & \multicolumn{2}{|c|}{$48 \mathrm{~h}$} \\
\hline & $4^{\circ} \mathrm{C}$ & Room temp. & $4^{\circ} \mathrm{C}$ & Room temp. & $4^{\circ} \mathrm{C}$ & Room temp. \\
\hline \multicolumn{7}{|c|}{ Motility \% (February - March) } \\
\hline 15 & $98 \pm 1.5$ & $95 \pm 3$ & $75 \pm 3$ & $25 \pm 3$ & $45 \pm 4$ & 0 \\
\hline 30 & $91 \pm 5$ & $88 \pm 3$ & $64 \pm 6$ & $10 \pm 2$ & $36 \pm 3$ & 0 \\
\hline 45 & $82 \pm 7$ & $78 \pm 3$ & $45 \pm 3$ & $8 \pm 2$ & $32 \pm 4$ & 0 \\
\hline \multicolumn{7}{|c|}{ Motility \% (Sepember-October) } \\
\hline 15 & $98 \pm 1.5$ & $95 \pm 3$ & $75 \pm 3$ & $25 \pm 3$ & $45 \pm 4$ & 0 \\
\hline 30 & $91 \pm 5$ & $88 \pm 3$ & $64 \pm 6$ & $10 \pm 2$ & $36 \pm 3$ & 0 \\
\hline 45 & $82 \pm 7$ & $78 \pm 3$ & $45 \pm 3$ & $8 \pm 2$ & $32 \pm 4$ & 0 \\
\hline
\end{tabular}

most commonly used indicator of sperm quality since high motility is essential for success of fertilisation (Rurangwa et al., 2004). From the results of the present study, it could be inferred that refrigeration at $4^{\circ} \mathrm{C}$ can significantly reduce depletion of sperm motility post-stripping, in snowtrout.

\section{Sperm morphology}

Electron microscopy of $S$. plagiostomus spermatozoa revealed that they are uniflagellated and the head lack an acrosome. The midpiece has 4-6 mitochondria, proximal and distal centrioles. Flagellum was found to be composed of typical $9+2$ pairs of microtubules (Fig. 2). Sperm head was observed to be ovoid and $1.82 \mu \mathrm{m}$ long. Tail $(20.18 \mu \mathrm{m})$ part was the longest part of sperm and the mid piece was found ellipsoidal $(0.35 \mu \mathrm{m}$ long). The average total length of $S$. plagiostomus spermatozoa was $22.3 \mu \mathrm{m}$ (Table 4).

Scanning and transmission electron microscopy studies have revealed that there exist wide divergences in the organisation of teleost spermatozoa. Spermatozoa of external fertilisers have varying head shape (from spherical to elongate) and a much smaller mid piece region (Koch and Lambert, 1990; Jamieson, 1991; Gwo, 1995). The head shape of $S$. plagiostomus sperm in the present study was found to be ovoid. Ovoid shaped sperm head is a feature of fishes living in water bodies having fast water currents (Jamieson, 1991). This supports the assumption that shape of spermatozoa may have consequences in flow resistance and in the swimming behaviour, as the shape of sperm head supports the swimming pattern or swimming velocities of spermatozoa in fishes (Lahnsteiner and Patzner, 1990). Nuclear elongation in the spermatozoa was not observed in the present study while in other teleosts, nuclear elongation has been reported (Jones, 1988; Lahnsteiner and Patzner, 1990; Pecio and Rafinski, 1999). The midpiece was found ellipsoidal as in sympatric snowtrout S. richardsonii (Panwar, 2004). Transmission electron microscopy of sperm revealed a cytoplasmic channel separating the flagella from the plasma membrane (Fig. 2a-f), which has been recorded in many other teleosts 


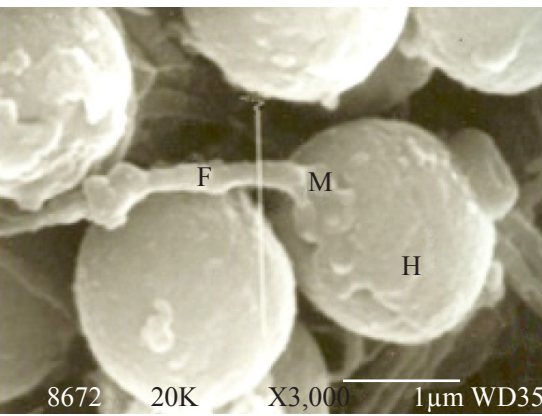

(a)

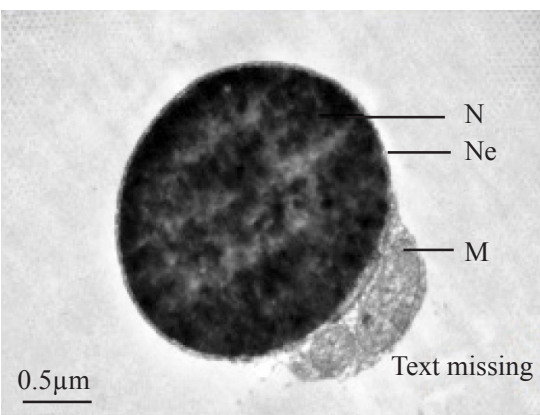

(d)

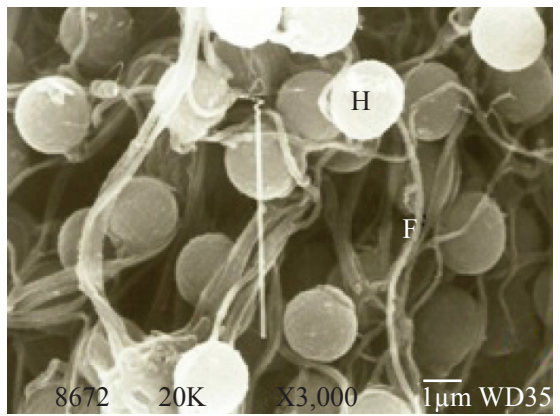

(b)

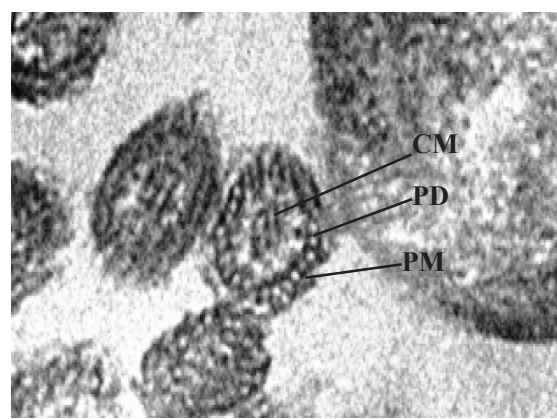

(e)

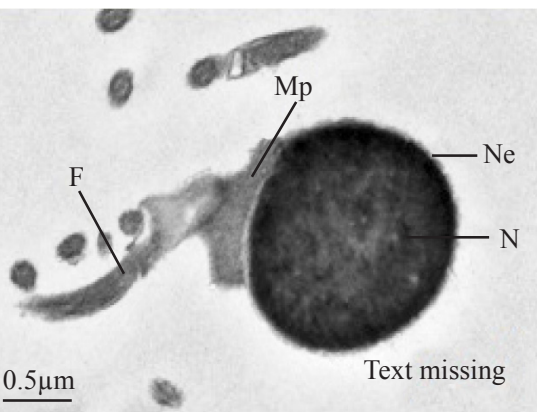

(c)

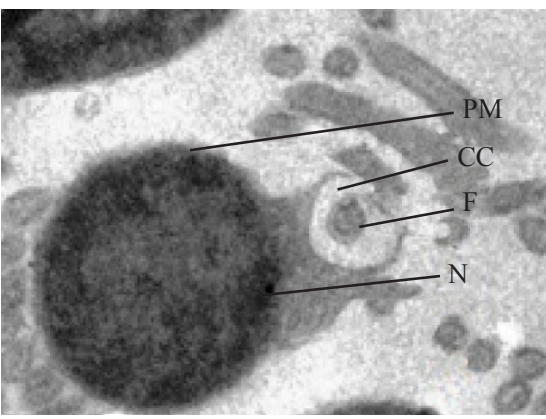

(f)

Fig. 2. Ultrastructure of the flagellum of S. plagiostomus. (a-b) - SEM showing Head (H), Midpiece (M) and Flagellum (F); (c-d) - TEM showing Nucleus (N), Nuclear envelope (Ne), Midpiece (Mp), Flagellum (F) and Mitochondria (M); (e) - TEM of flagella showing inner structure with 9+2 arrangement of peripheral doublets (PD), Central microtubules (CM) surrounded by plasma membrane (PM); (f) - TEM of sperm showing nucleus $(\mathrm{N})$ surrounded by the nuclear membrane $(\mathrm{NM})$ and the flagellum $(\mathrm{F})$ separated by cytoplasmic channel (CC)

Table 4. Biometric features of spermatozoa $(\mathrm{N}=38)$

\begin{tabular}{llllll}
\hline Head shape & Head length $(\mu \mathrm{m})$ & Mid piece & Mid piece length $(\mu \mathrm{m})$ & Flagella $(\mu \mathrm{m})$ & Total length $(\mu \mathrm{m})$ \\
\hline Ovoid & $1.82 \pm 0.24$ & Ellipsoidal & $0.35 \pm 0.07$ & $20.18 \pm 0.79$ & $22.3 \pm 3$ \\
\hline
\end{tabular}

(Mattei, 1991; Gwo, 1995). In comparison to the sperm of IMCs, the sperm of $S$. plagiostomus was found to be longer than that of catla and mrigal, while shorter than that of rohu.

Results of the present study would be helpful in selection of male $S$. plagiostomus yielding good quality milt, which in turn would help in formulating enhanced methods for artificial fertilisation and sperm cryopreservation strategies.

\section{Acknowledgements}

Authors are grateful to the Council of Scientific and Industrial Research (CSIR), New Delhi for providing CSIR-JRF to the first author. The authors are also thankful to All India Institute of Medical Sciences, New Delhi and Punjab University, Chandigarh for technical assistance in TEM and SEM studies.

\section{References}

Adewumi, A., Olaleye, V. and Adesulu, E. 2005. Egg and sperm quality of the African catfish, Clarias gariepinus (Burchell) broodstock fed differently heated soybean-based diets. Res. J. Agric. Biol. Sci., 1: 17-22.

Agarwal, N. and Raghuvanshi, S. 2009. Spermatocrit and sperm density in snowtrout (Schizothorax richardsonii): Correlation and variation during the breeding season. Aquaculture, 291: 61-64. doi:10.1016/j. aquaculture. 2009.03.002.

Agarwal, N. and Raghuvanshi, S. 2013. Characterisation and short-term storage of semen of a coldwater Himalayan fish species. Biojournal, 8: 1-8.

Alavi, S., Rodina, M., Policar, T., Kozak, P., Psenicka, M. and Linhart, O. 2007. Semen of Perca fluviatilis L.: Sperm volume and density, seminal plasma indices and effects of dilution ratio, ions and osmolality on sperm motility. Theriogenology, 68: 276-283. doi:10.1016/j. theriogenology.2007.05.045.

Alavi, S. M. H. and Cosson, J. 2006. Sperm motility in fishes. (II) Effects of ions and osmolality: a review. Cell Biol. Int. 30:1-14. doi:10.1016/j.cellbi.2005.06.004. 
Alavi, S. M. H., Linhart, O., Coward, K. and Rodina, M. 2008. Fish spermatology: implication for aquaculture management. Alpha Science Ltd., Oxford, UK, p. 397-460.

Alavi, S. M. H., Psenicka, M., Rodina, M., Policar, T. and Linhart, O. 2008a. Changes of sperm morphology, volume, density and motility and seminal plasma composition in Barbus barbus (Teleostei: Cyprinidae) during the reproductive season. Aquat. Living Resour., 21: 75-80. doi:10.1051/alr:2008011.

Aliniya, M., Khara, H., Noveiri, S. B. and Dadras, H. 2013. Influence of age of common carp (Cyprinus carpio) broodstock on reproductive traits and fertilisation. Turk. J. Fish. Aquat. Sci., 13: 19-25. doi: 10.4194/1303-2712v13_1_03.

Baccetti, B., Burrini, A. G., Gibertini, G., Mazzini, M. and Zerunian, S. 1984. Fish germinal cells. I. Comparative spermatology of seven cyprinid species. Gamete Res., 10: 373-396.

Barsagade, D. D. and Gharade, S. A. 2014. Ultrastructural studies on the neurosecretory cells in the pars intercerebralis of Larvae of tasar silkworm, Antheraea mylitta (D) eco-race Bhandara (Lepidoptera: Saturniidae). Int. J. Indust. Entomol., 29: 120-127. doi: 10.1002/mrd.1120100405.

Basavaraja, N., Ahmed, I. and Hegde, S. 1998. Short term and long term preservation of fish gametes with special reference to Mahseer (Tor khudree) spermatozoa. Fish. Chimes, 18: 17-19.

Billard, R., Cosson, J., Perchec, G. and Linhart, O. 1995. Biology of sperm and artificial reproduction in carp. Aquaculture, 129: 95-112. doi:10.1016/0044-8486(94)00231-C.

Bligh, E. G. and Dyer, W. J. 1959. A rapid method of total lipid extraction and purification. Can. J. Biochem. Physiol., 37: 911-917. doi: 10.1139/059-099.

Bouck, G. R. and Jacobson, J. 1976. Estimation of salmonid sperm concentration by microhematocrit technique. Trans. Am. Fish. Soc., 105: 534-535.

Cejko, B. I., Krejszeff, S., Judycka, S., Sarosiek, B., Dietrich, M., Kucharczyk, D. and Kowalski, R. K. 2014. Sperm quality and selected biochemical markers of seminal plasma at the beginning of the reproductive period of common carp, Cyprinus carpio L. Aquac. Int., 22: 111-122. doi: 10.1007/ s10499-013-9672-3.

Ciereszko, A. 2008. Chemical composition of seminal plasma and its physiological relationship with sperm motility, fertilising capacity and cryopreservation success in fish, In: Fish spermatology. Alpha Science Ltd, Oxford, UK, p. $215-240$

Ciereszko, A., Glogowski, J. and Dabrowski, K. 2000. Biochemical characteristics of seminal plasma and spermatozoa of freshwater fishes. Cryopreservation in aquatic species, World Aquaculture Society, Baton Rouge, p. 20-48.
Cosson, J. 2004. The ionic and osmotic factors controlling motility of fish spermatozoa. Aquac. Int., 12: 69-85. doi: 10.1023/B:AQUI.0000017189.44263.bc.

Cosson, J., Billard, R., Cibert, C., Dreanno, C. and Suquet, M. 1999. Ionic factors regulating the motility of fish sperm. In: Gagnon, C. (Eds.), The male gamete: from basic to clinical applications. Cache Rive Press, Vienna, p. 161-186.

Day, F. 1958. The fishes of India: Being a natural history of the fishes known to inhabit the seas and freshwaters of India, Burma and Ceylon, vol. 1, William Dawson and Sons Ltd., London, $564 \mathrm{pp}$.

Furbock, S., Lahnsteiner, F. and Patzner, R. A. 2009. A fine structural review on the spermatozoa of Cyprinidae with attention to their phylogenetic implications. Histol. Histopathol., 24: 1233-1244.

Gwo, J. C.1995. Spermatozoan ultrastructure of the teleost fish Acanthopagrus latus (Perciformes: Sparidae) with special reference to the basal body. J. Submicrosc Cytol. Pathol., 27: 391-396.

Islam, M. S. and Akhter, T. 2011. Tale of fish sperm and factors affecting sperm motility: a review. Adv. Life Sci., 1: 11-19. doi: $10.5923 /$ j.als.20110101.03.

Jamieson, B. G. M. 1991. Fish evolution and systematics: evidence from spermatozoa with a survey of lophophorate, echinoderm and protochordate sperm and an account of gamete cryopreservation. Cambridge University Press. Cambridge, 319 pp.

Jones, P. R. and Butler, R. D. 1988. Spermatozoon ultrastructure of Platichthys flesus. J. Ultra. Mol. Struct. R., 98: 71-82.

Koch, R. A. and Lambert, C. C. 1990. Ultrastructure of sperm, spermiogenesis and sperm-egg interactions in selected invertebrates and lower vertebrates which use external fertilisation. J. Electron Micr. Tech., 16: 115-154.

Lahnsteiner, F., Berger, B., Weismann, T. and Patzner, R. 1996 Motility of spermatozoa of Alburnus alburnus (Cyprinidae) and its relationship to seminal plasma composition and sperm metabolism. Fish. Physiol. Biochem., 15:167-179. doi: 10.1007/BF01875596.

Lahnsteiner, F. and Patzner, R. 1990. Spermiogenesis and structure of mature spermatozoa in blenniid fishes (Pisces, Blenniidae). J. Submicrosc. Cytol. Pathol., 22: 565-576.

Linhart, O., Gela, D., Rodina, M. and Kocour, M. 2004. Optimisation of artificial propagation in European catfish, Silurus glanis L. Aquaculture, 235: 619-632. doi:10.1006/ cryo.2000.2284

Linhart, O., Rodina, M. and Cosson, J. 2000. Cryopreservation of sperm in common carp Cyprinus carpio: sperm motility and hatching success of embryos. Cryobiology, 41: 241-250. doi:10.1006/cryo.2000.2284 
Lowary, O. H., Rosenbrough, N. J., Farr, A. L. and Randall, R. J. 1951. Protein measurement with the folin phenol reagent. J. Biol. Chem., 192: 265-275.

Mattei, X. 1991. Spermatozoan ultrastructure and its systematic implications in fishes. Can. J. Zool., 69: 3038-3055.

McCready, R., Guggolz, J., Silviera, V. and Owens, H. 1950. Determination of starch and amylase in vegetables. Anal. Chem., 22: 1156-1158. doi: 10.1021/ac60045a016.

Miura, T. and Miura, C. I. 2003. Molecular control mechanisms of fish spermatogenesis. Fish Physiol. Biochem., 28: 181-186. doi: 10.1023/B:FISH.0000030522.71779.47.

Morisawa, M., Oda, S., Yoshida, M. and Takai, H. 1999. Transmembrane signal transduction for the regulation of sperm motility in fishes and ascidians. In: Gagnon, C. (Eds.), The male gamete: from basic science to clinical applications. Cache River Press, Vienna, p. 149-160.

Panwar, S. 2004. Qualitative and quantitative study of spermatozoa of three hill stream food fishes of Garhwal Himalaya, D. Phill thesis, Hemwati Nandan Bahuguna Garhwal University, Srinagar Garhwal, Uttarakhand, India

Pecio, A. and Rafinski, J. 1999. Spermiogenesis in Mimagoniates barberi (Teleostei: Ostariophysi: Characidae), an oviparous, internally fertilising fish. Acta Zoologica, 80: $35-46$.

Rakitin, A., Ferguson, M. M. and Trippel, E. A. 1999. Spermatocrit and spermatozoa density in Atlantic cod (Gadus morhua): correlation and variation during the spawning season. Aquaculture, 170: 349-358. doi:10.1016/ S0044-8486(98)00417-7.

Rurangwa, E., Kime, D., Ollevier, F. and Nash, J. 2004. The measurement of sperm motility and factors affecting sperm quality in cultured fish. Aquaculture, 234: 1-28. doi: 10.1016/j.aquaculture.2003.12.006
Shaliutina-Kolesova, A., Gazo, I., Cosson, J. and Linhart, O. 2013. Comparison of oxidant and antioxidant status of seminal plasma and spermatozoa of several fish species. Czech J. Ani. Sci., 58: 313-320.

Singh, N., Bahuguna, S. and Bhatt, K. 1993. The profile of river ecosystem, food and feeding habits of hills-tream fishes and consequences of recent enviromental degradation in Garhwal Himalaya. Acta Ichthyol. Piscat., 23: 3-30.

Stoss, J. 1983. Fish gamete preservation and spermatozoan physiology. Fish physiol., 9: 305-350.

Tvedt, H. B., Benfey, T. J., Martin-Robichaud, D. J. and Power, J. 2001. The relationship between sperm density, spermatocrit, sperm motility and fertilisation success in Atlantic halibut, Hippoglossus hippoglossus. Aquaculture, 194: 191-200.

Verma, D., Routray, P., Dash, C., Dasgupta, S. and Jena, J. 2009. Physical and biochemical characteristics of semen and ultrastructure of spermatozoa in six carp species. Turk. $J$. Fish. Aquat. Sci., 9: 67-76.

Vinod, B. and Basavaraja, N. 2010. Reproductive biology of the Indian sandwhiting, Sillago sihama (Forsskal) - maturity stages, fecundity, spermatozoa and histology of gonads. Indian. J. Fish., 57: 21-30.

Wei, Q., Li, P., Psenicka, M., Alavi, S. H., Shen, L., Liu, J., Peknicova, J. and Linhart, O. 2007. Ultrastructure and morphology of spermatozoa in Chinese sturgeon (Acipenser sinensis Gray 1835) using scanning and transmission electron microscopy. Theriogenology, 67: 1269-1278. doi:10.1016/j.theriogenology.2007.02.003. 